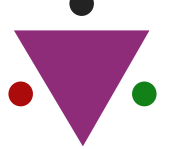

IJCRR

Section: Healthcare

Sci. Journal Impact

Factor: $6.1(2018)$

ICV: 90.90 (2018)

(c) (i) (3)

Copyright@IJCRR

\title{
Awareness and Initiatives Taken by the Residents of Condominium in a Metro City to Prevent Infection (COVID-19) Spread - A Survey
}

\author{
Trisha Sasikumar ${ }^{1}$, Gayathri R², Ganesh Lakshmanan'3, Vishnupriya V ${ }^{4}$
}

\begin{abstract}
'Saveetha Dental College and Hospital, Saveetha Institute of Medical and Technical Sciences (SIMATS), Saveetha University, Chennai, India; 2Assistant Professor, Department of Biochemistry, Saveetha Dental College and Hospitals, Saveetha Institute of Medical and Technical Sciences

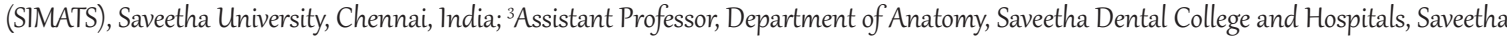
Institute of Medical and Technical Sciences (SIMATS), Saveetha University, Chennai, India.; ${ }^{2}$ Professor, Department of Biochemistry, Saveetha Dental College and Hospitals, Saveetha Institute of Medical and Technical Sciences (SIMATS), Saveetha University, Chennai, India.
\end{abstract}

\section{ABSTRACT}

Introduction: A highly infectious disease COVID 19 caused by Coronavirus is rapidly spreading throughout the globe. Severe respiratory syndrome coronavirus-2 (SARS-CoV-2) is the causative factor for this disease. It has affected about 210 countries worldwide, resulting in over 1,26,000 deaths. Being a droplet infection, it spreads between people having close contact. It is contracted through small droplets produced by sneezing, coughing, and talking. The droplet could also fall on the ground and onto other surfaces and people touching these surfaces could also contract the infection. The role of the public in this is extremely crucial. The citizens should abide by the rules of social distancing strictly. Everyone must try to stay at home as much as possible, even though there is an exception for those in essential services like government jobs and medical facilities. Going out should be avoided as much as possible, people should only go if it is absolutely necessary and even then not meet people or stand in groups. The study aimed to assess the awareness and initiative taken by the condominium office administrators and residents among the metro cities during an infection (COVID-19) spread.

Materials and Methods: A questionnaire was distributed through an online Google form link to about 100 people living in condominiums belonging to all age groups. The results were collected and analyzed statistically using SPSS.

Results: The majority of the study population responded positively to the awareness and initiatives taken by condominium authorities and strict rules were laid.

Conclusion: The spread of awareness and the strict decisions taken by the public is very essential to fight against a pandemic such as COVID 19.

Key Words: Awareness, Initiatives taken, Condominium residents, Outbreak, COVID-19, Survey

\section{INTRODUCTION}

COVID 19 is an infectious disease caused by severe respiratory syndrome coronavirus-2 (SARS-CoV-2). About 1.98 million cases have been reported worldwide by 15 th April 2020 ${ }^{1}$ Over the past decade, research in nanotechnology ${ }^{2,3}$ cancer biology ${ }^{4}$ analysing the cytotoxicity of the substance, nanodrug modelling ${ }^{5-10}$ various in vivo studies ${ }^{11,12}$ phytochemical, and anti-oxidant analysis ${ }^{13,14,15}$ analysis of the benefits of various natural products and other advanced research have taken a priority in the scientific world. Now the pandemic COVID 19 has taken a major part of the research. In this research, the main focus is to learn how people living in con- dominiums in metro cities are able to cope up and manage to get themselves prevented from infection. It has been reported in over 126,000 deaths worldwide. Being a droplet infection, it is easily communicable and spreads between people having close contact. It spreads via small droplets that could fall on the ground and other surfaces and the people touching these contaminated surfaces contract the infection. Maintaining people's hygiene and disinfecting common grounds regularly is crucial to keep a community safe ${ }^{16,17}$. Next importantly, people staying in condominium complexes should be aware of the current situation and must adhere to all the rules laid down by the government strictly. Social distancing must be practiced and kids and old aged people should

\section{Corresponding Author:}

Dr. Gayathri R, Assistant Professor, Department of Biochemistry, Saveetha Dental College and Hospitals, Saveetha Institute of Medical and Technical Sciences (SIMATS), Saveetha University, Chennai-77, India; Phone: +9197106 80545; Email:gayathri.sdc@saveetha.com

ISSN: 2231-2196 (Print)

Received: 27.07 .2020
ISSN: 0975-5241 (Online)

Revised: 20.08 .2020
Accepted: 24.09 .2020
Published: 20.10 .2020 
stay indoors and refrain from using common grounds ${ }^{18}$. The study is potential and needs to be understood that this is an important problem worldwide and has caused major losses. It is the need of the hour for people to keep themselves safe and aware in order to fight the infection. There has been no found cause, treatment, or vaccination to cure the infection, so it is best to prevent themselves from acquiring the disease. The challenges to this are poor cooperation from the citizens and the disease being novel, we do not know anything in detail about it; scientists are still researching to find out ${ }^{19}$. We live as a community, thus an outbreak like this can be fought only when everyone cooperates between them. Nowadays, in metro cities, people opt to live in big condominiums, since there are an increasing number of people dwelling per square meter. Thus, as a community, the condominium dwellers need to face an emergency situation like an infection outbreak. Even if there is a small disagreement or conflict among the community, might lead to an increased risk for the entire community. Fighting against infection or an emergency will certainly show much-needed cooperation. Thus to work as a team, these communities require good office bearers, who can think positively and instruct them according to the requirements ${ }^{20}$. The aim of this study is to know how much knowledge and awareness the office administrators and the residents have to fight against this fast-spreading disease and the initiatives they have taken for the safety and welfare of the residents. Different other studies and support over current situations show that community decision making plays a key role in overcoming infectious outbreak ${ }^{21}$. The study aimed to assess the awareness and initiatives taken by the residents of condominiums among the metro cities during an infection (COVID-19) spread.

\section{MATERIAL AND METHODS}

Self-administrated questionnaires based on the awareness and initiatives taken by the residents and office administrators of the condominium comprising 10 questions were distributed on an online Google form link: "https://docs.google. com/forms/d/e/1FAIpQLSeITyMb6a4zGIVBdIbaIQAdh3 HqmH39KfUIA0KAjbuvjVfDcQ/viewform?usp=sf_link" The study population included people living in condominiums and of age 18 years and above. The participants were explained about the purpose of the study in detail; questions were carefully studied and corresponding answers were marked by the participants.

\section{Statistical Analysis}

The data was collected and analyzed statistically using SPSS software version 20 . The study was approved by the Institutional review board.

\section{RESULTS}

The collected results data was analyzed and revealed that the majority of respondents said the condominium administrators and residents took the initiative to control the spread of infection during the outbreak. The total participants responded positively, that outright proves to be a positive report.

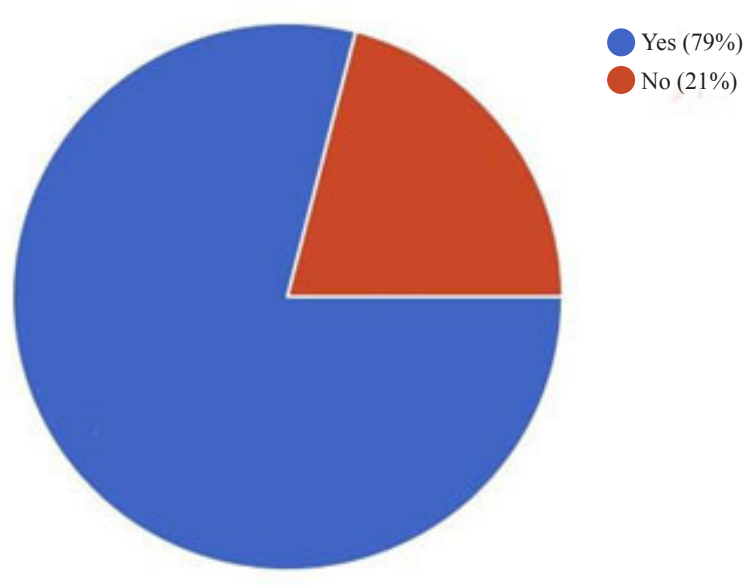

Figure 1: Figure represents the distribution of participants based on their opinion towards disinfecting their condominium premises to avoid infection, where $79 \%$ (blue) of the study participants agree and $21 \%$ (red) of them feel that it is not necessary.

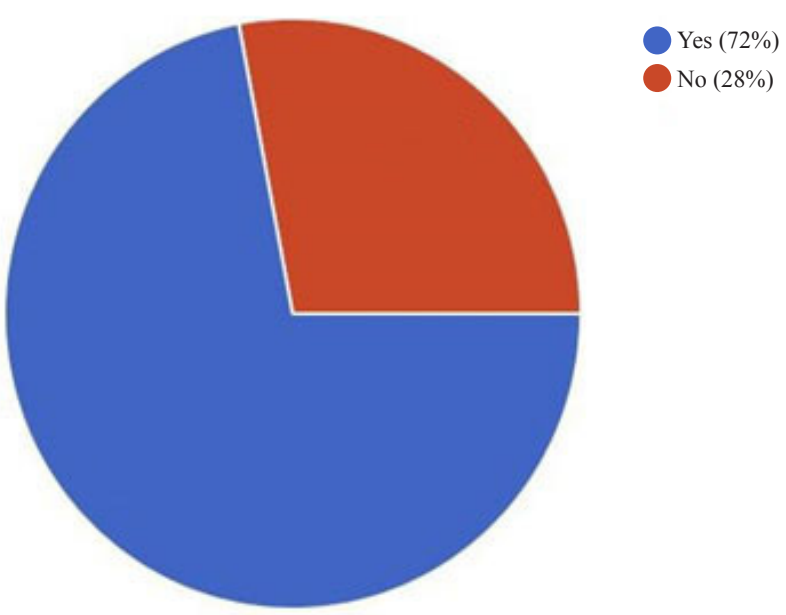

Figure 2: Figure represents the distribution of participants based on their opinion towards cooperating with the new rules to be laid by the association to prevent COVID 19 infection, where $72 \%$ (blue) of the study participants agree and $21 \%$ (red) of them feel that it is not necessary. 


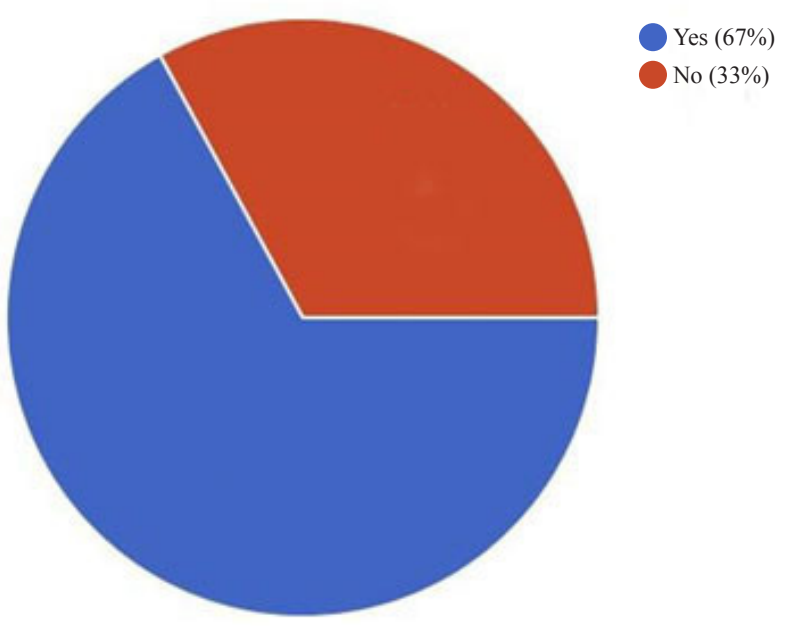

Figure 3: Figure represents the distribution of participants based on their opinion towards strictly locking their condominium gate after 6 pm to prevent COVID 19 infection, where $67 \%$ (blue) of the study participants agree and $33 \%$ (red) of them feel that it is not necessary.

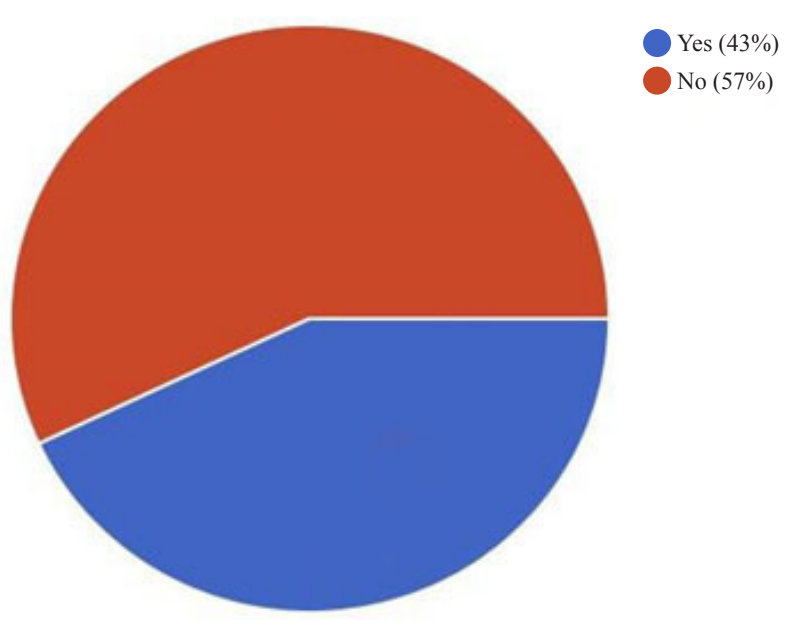

Figure 4: Figure represents the distribution of participants based on their opinion towards not to permit vegetable or fruit sellers inside their condominium to prevent COVID 19 infection, where only $43 \%$ (blue) of the study participants agreed to it and $57 \%$ (red) of them felt that as vegetables and fruits are essential, they wanted those sellers to be allowed.

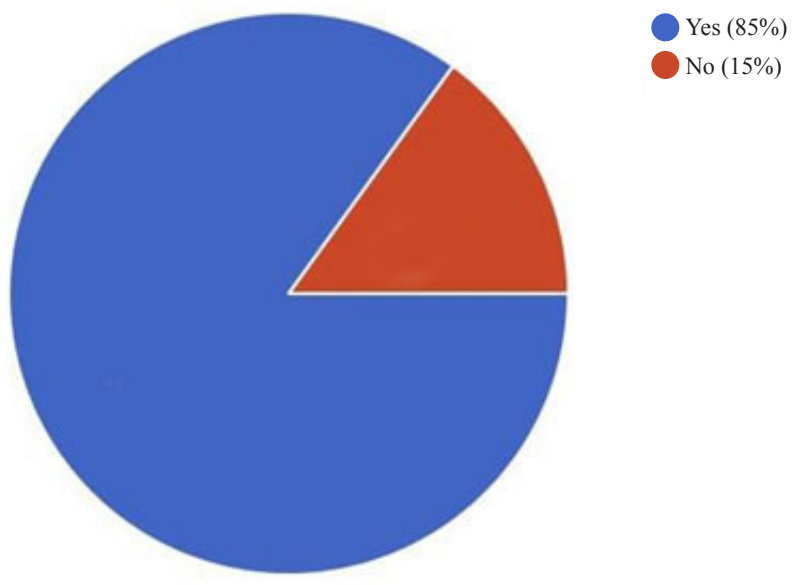

Figure 5: Figure represents the distribution of participants based on their opinion towards not permitting children to play in the common area of their condominium to prevent COVID 19 infection, where to this a majority of $85 \%$ (blue) of the study participants agreed to it and $15 \%$ (red) of them felt not necessary.

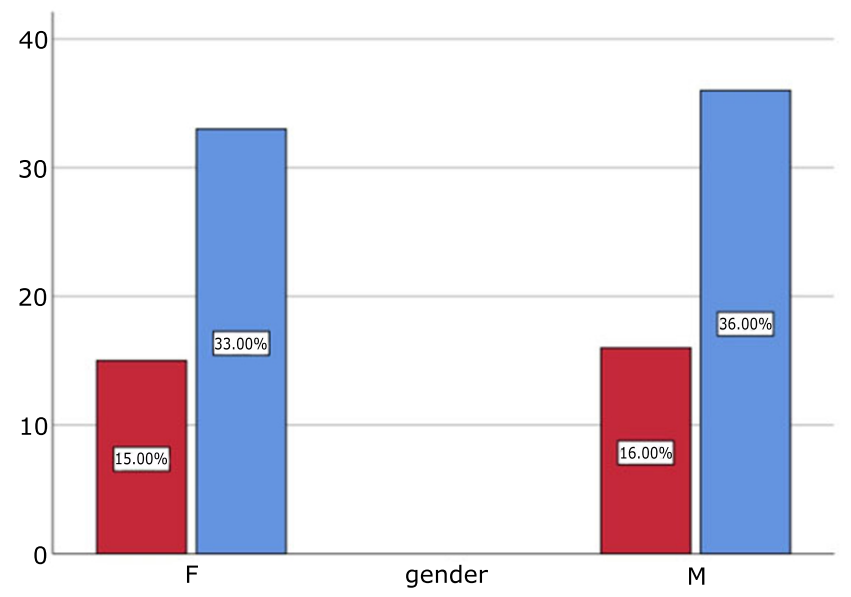

Figure 6: Bar chart showing the association between gender and their opinion to hold a meeting to discuss the rules to be laid to prevent COVID infection. X-axis represents Gender, Yaxis represents the number of responses who wanted to hold a meeting (Blue) and who don't want a meeting (Red). 33 females and 36 males agreed to have a meeting. Pearson's Chi-square analysis $=101.003$, Pearson's Chi-square analysis done, $p$ value $=0.000,(<0.05)$, statistically significant. The majority of male and female participants were willing to hold meetings regarding COVID. 


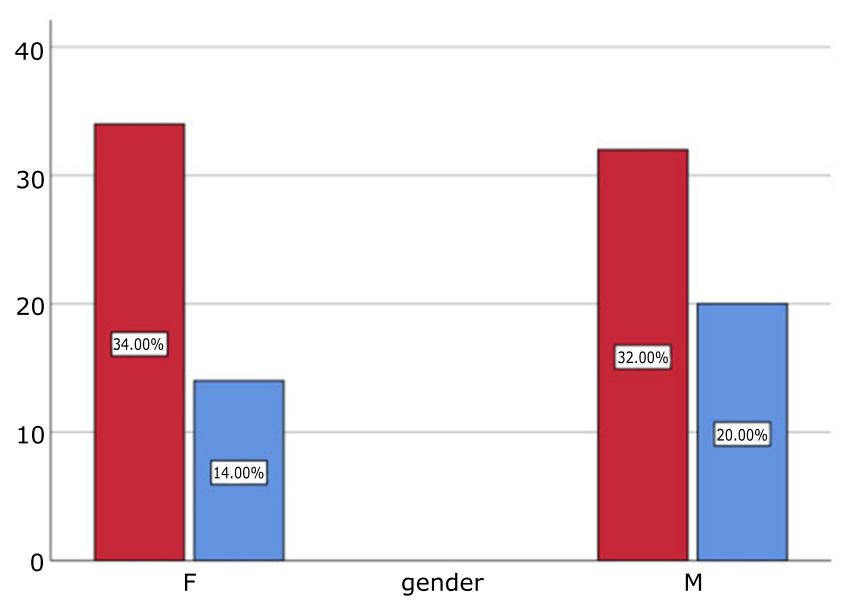

Figure 7: Bar chart showing the association between gender and their opinion not to allow servant maids inside their condominium to prevent COVID infection. X-axis represents Gender, Y-axis represents the number of responses; Blue- restrict the entry of servant maids; Red - who want their maids to come. Only 14 females and 20 males restricted the entry of maids to prevent COVID infection. The graph depicts the fact that when it comes to house help, people want to ease their norms. Pearson's Chi-square analysis $=101.971, \mathrm{P}-0.000, \mathrm{P}<0.05$, statistically significant. The majority of the male and female respondents did not restrict the entry of maids.

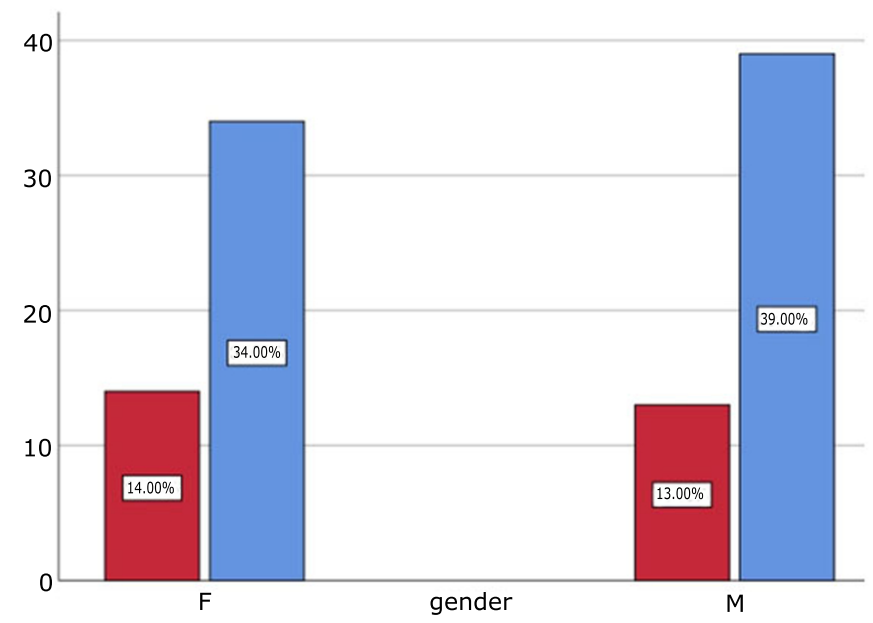

Figure 8: Bar chart showing the association between gender and their opinion to strictly instruct security not to allow visitors to enter the apartment premises in order to prevent COVID infection. X-axis represents Gender, Y-axis represents the number of responses who wanted to restrict the entry of visitors (Blue) and who wanted to allow entry of visitors (Red). 34 females and 39 males restricted the entry of visitors. Pearson's Chi-square analysis $=101.222, \mathrm{P}$ value $=0.000, \mathrm{P}<0.05$, statistically significant. The majority of male and female respondents restricted the entry of visitors.
From the survey results, Figure 1 shows if steps have been taken to disinfect the condominium premises, a majority of the participants $(79 \%)$ said that steps were being taken while $21 \%$ did not think so. Figure 2 depicts if all the residents of the condominium cooperated with the given instructions, a majority of the participants (72\%) said Yes while $25 \%$ said No. Another study proves public cooperation is essential for the control and prevention of an infection outbreak ${ }^{22}$. Figure 3 depicts if the condominium gates are locked strictly after 6 PM, a majority of $67 \%$ said Yes it is locked while 33\% said No. Another study talks about how strict rules will ensure the betterment of society ${ }^{23}$. Figure 4 depicts if the condominium association allowed fruit and vegetable vendors inside the condominium premises, only $43 \%$ didn't allow vendors inside while $53 \%$ allowed vendors inside. Figure 5 portrays if children are restricted from the common area, A majority of the participants said yes $(80 \%)$ they are restricted while only $20 \%$ said no. Another study talks about the initiatives taken at an Australian residential aged care facilities ${ }^{24,25}$. Figure 6 depicts if the residents were educated about the current situation a majority $85 \%$ answered positively when only $18 \%$ answered negatively Figure 6 depicts if all the office bearers of the condominium have a meeting to lay instructions owing to this infectious situation, about $89 \%$ of the total population responded positively. Figure 7 shows if servant maids were allowed to enter the condominium during the lockdown, the majority of the participants $66 \%$ said no, the maids were not allowed whereas $34 \%$ said they were allowed ${ }^{26,27}$. Washbasin and soaps have been arranged at the entrance to the condominium, the majority of the residents $74 \%$ said that soap and water are provided for cleansing while $26 \%$ says it is not provided ${ }^{28,29}$. Another study talks about how structures are controlled in order to prevent key infections ${ }^{30,31}$. Figure 8 shows if the security person is strictly instructed to not allow any visitors inside, the majority of the participants said Yes, the security has been instructed not to let any visitors inside while $27 \%$ said No. The literature review reveals a number of reports on how to maintain rules strictly in order to protect themselves ${ }^{32,33}$.

When it comes to health and the preventive measures to be followed to keep us healthy, the role of women is more proactive than males. The study results also depict the same. The results are very positive and depict the cooperative nature of condominium dwellers especially during an emergency situation. Moreover, people residing in condominiums also take initiatives to lead during necessity; again this proves to be a positive sign of cooperation.

\section{CONCLUSION}

On a whole, from the survey, it is evident that, though the majority of the people dwelling in cities live as a micro family when a situation hits an emergency, they team up and 
try to coordinate for the well being of the society. Credits have to be given especially for the condominium residential society managers and secretaries, as they do extra work to extend safety for their co dwellers. This study was conducted to understand the awareness of the people living in big condominiums and the initiatives taken by them to control the infection outbreak. The results of the study as a whole depict a positive approach of the condominium members in metro cities to fight and protect themselves during a pandemic.

\section{REFERENCES}

1. Priya VV, Jainu M, Mohan SK. Biochemical Evidence for the Antitumor Potential of Linn. On Diethylnitrosamine-Induced Hepatic Carcinoma. Pharmacogn Mag [Internet]. 2018 Apr;14(54):186-90. Available from: http://dx.doi.org/10.4103/ pm.pm_213_17

2. Wu F, Z Zu J, Li G, Wang J, Veeraraghavan VP, Krishna Mohan $\mathrm{S}$, et al. Biologically synthesized green gold nanoparticles from induce growth-inhibitory effect on melanoma cells (B16). Artif Cells Nanomed Biotechnol [Internet]. 2019 Dec;47(1):3297305. Available from: http://dx.doi.org/10.1080/21691401.2019. 1647224

3. Ke Y, Al Aboody MS, Alturaiki W, Alsagaby SA, Alfaiz FA, Veeraraghavan VP, et al. Photosynthesized gold nanoparticles from Catharanthus roseus induces caspase-mediated apoptosis in cervical cancer cells (HeLa). Artif Cells Nanomed Biotechnol [Internet]. 2019 Dec;47(1):1938-46. Available from: http:// dx.doi.org/10.1080/21691401.2019.1614017

4. Ma Y, Karunakaran T, Veeraraghavan VP, Mohan SK, Li S. Sesame Inhibits Cell Proliferation and Induces Apoptosis through Inhibition of STAT-3 Translocation in Thyroid Cancer Cell Lines (FTC-133). Biotechnol Bioprocess Eng [Internet]. 2019 Aug 3;24(4):646-52. Available from: http://link.springer. com/10.1007/s12257-019-0151-1

5. Li Z, Veeraraghavan VP, Mohan SK, Bolla SR, Lakshmanan H, Kumaran S, et al. Apoptotic induction and anti-metastatic activity of eugenol encapsulated chitosan nanopolymer on rat glioma C6 cells via alleviating the MMP signaling pathway. J Photochem Photobiol B [Internet]. 2020 Jan;203:111773. Available from: http://dx.doi.org/10.1016/j.jphotobiol.2019.111773

6. Chen F, Tang Y, Sun Y, Veeraraghavan VP, Mohan SK, Cui C. 6-shogaol, a active constiuents of ginger prevents UVB radiation mediated inflammation and oxidative stress through modulating $\mathrm{NrF} 2$ signaling in human epidermal keratinocytes (HaCaT cells). J Photochem Photobiol B [Internet]. 2019 Aug;197:111518. Available from: http://dx.doi.org/10.1016/j. jphotobiol.2019.111518

7. Wang Y, Zhang Y, Guo Y, Lu J, Veeraraghavan VP, Mohan SK, et al. Synthesis of Zinc oxide nanoparticles from Marsdenia tenacissima inhibits the cell proliferation and induces apoptosis in laryngeal cancer cells (Hep-2). J Photochem Photobiol B [Internet]. 2019 Dec;201:111624. Available from: http://dx.doi. org/10.1016/j.jphotobiol.2019.111624

8. Gan H, Zhang Y, Zhou Q, Zheng L, Xie X, Veeraraghavan VP, et al. Zingerone induced caspase-dependent apoptosis in MCF7 cells and prevents 7,12-dimethylbenz(a)anthracene-induced mammary carcinogenesis in experimental rats. J Biochem Mol Toxicol [Internet]. 2019 Oct;33(10):e22387. Available from: http://dx.doi.org/10.1002/jbt.22387
9. Rengasamy G, Venkataraman A, Veeraraghavan VP, Jainu M. Cytotoxic and apoptotic potential of Myristica fragrans Houtt. (mace) extract on human oral epidermal carcinoma KB cell lines. Braz J Pharm Sci [Internet]. 2018 Nov 29;54(3):915. Available from: http://www.scielo.br/scielo.php?script $=$ sci arttext\&pid=S1984-82502018000300629\&lng=en\&tlng=en

10. Ramya G, Vishnu Priya V, Gayathri R. CYTOTOXICITY OF STRAWBERRY EXTRACT ON ORAL CANCER CELL LINE. Asian J Pharm Clin Res [Internet]. 2018 Sep 7;11(9):353. Available from: https://innovareacademics.in/journals/index. php/ajpcr/article/view/25955

11. Ponnulakshmi R, Shyamaladevi B, Vijayalakshmi P, Selvaraj J. In silico and in vivo analysis to identify the antidiabetic activity of beta sitosterol in adipose tissue of high fat diet and sucrose induced type- 2 diabetic experimental rats. Toxicol Mech Methods [Internet]. 2019 May;29(4):276-90. Available from: http:// dx.doi.org/10.1080/15376516.2018.1545815

12. Rengasamy G, Jebaraj DM, Veeraraghavan VP, Mohan SK. Characterization, Partial Purification of Alkaline Protease from Intestinal Waste of Scomberomorus Guttatus and Production of Laundry Detergent with Alkaline Protease Additive. Indian Journal of Pharmaceutical Education and Research [Internet]. 2016 [cited 2020 Jun 20];50(2s). Available from: https://www. ijper.org/article/413

13. Mohan SK, Veeraraghavan VP, Jainu M. Effect of pioglitazone, quercetin, and hydroxy citric acid on vascular endothelial growth factor messenger RNA (VEGF mRNA) expression in experimentally induced nonalcoholic steatohepatitis (NASH) [Internet]. Vol. 45, TURKISH JOURNAL OF MEDICAL SCIENCES. 2015. p. 542-6. Available from: http://dx.doi.org/10.3906/ sag-1404-136

14. Shukri NMM, Vishnupriya V, Gayathri R, Mohan SK. Awareness in childhood obesity. Intern Jour Contemp Microbiol [Internet]. 2016;9(10):1658. Available from: http://www.indianjournals.com/ijor.aspx?target $=$ ijor:rjpt $\&$ volume $=9 \&$ issue $=10 \&$ article $=033$

15. Menon A, Priya V V, Gayathri R. Preliminary Phytochemical Analysis and Cytotoxicity Potential of Pineapple Extract on Oral Cancer Cell Lines. Asian J Pharm Clin Res [Internet]. 2016 Sep 26;140. Available from: http://www.innovareacademics.in/journals/index.php/ajpcr/article/view/13313

16. Starr R. Taking the right precautions to eliminate fire hazards [Internet]. Vol. 21, Nursing and Residential Care. 2019. p. 42-4. Available from: http://dx.doi.org/10.12968/nrec.2019.21.1.42

17. Sargent M. Preparing for pandemics [Internet]. Vol. 456, Nature. 2008. p. 574-574. Available from: http://dx.doi. org/10.1038/456574a

18. Hsia L. AIDS Taking universal precautions seriously [Internet]. Vol. 38, Journal of Nurse-Midwifery. 1993. p. 63-4. Available from: http://dx.doi.org/10.1016/0091-2182(93)90139-8.

19. Cleary PD. Why people take precautions against health risks [Internet]. Taking Care. 1987. p. 119-49. Available from: http:// dx.doi.org/10.1017/cbo9780511527760.009

20. Haimar AE, El Haimar A, Santos JR. Modeling Uncertainties in Workforce Disruptions from Influenza Pandemics Using Dynamic Input-Output Analysis [Internet]. Vol. 34, Risk Analysis. 2014. p. 401-15. Available from: http://dx.doi.org/10.1111/ risa. 12113

21. Leitner S. On the dynamics emerging from pandemics and infodemics [Internet]. Available from: http://dx.doi.org/10.31234/ osf.io/nqru6

22. Sansom C. Preparing for pandemics: no time to lose [Internet]. Vol. 17, The Lancet Infectious Diseases. 2017. p. 152. Available from: http://dx.doi.org/10.1016/s1473-3099(17)30023-3. 
23. M"uhlherr B, Petersson HP, Weiss RM. Fixed Apartments [Internet]. Princeton University Press. 2017. Available from: http:// dx.doi.org/10.23943/princeton/9780691166902.003.0025

24. Institute of Medicine, Board on Global Health, Forum on Microbial Threats. Learning from SARS: Preparing for the Next Disease Outbreak: Workshop Summary [Internet]. National Academies Press; 2004. 376 p. Available from: https://play.google. com/store/books/details?id=GSY0Tjq_M74C

25. Davis D, Siu HF, of Anthropology Helen. Sars: Reception and Interpretation in Three Chinese Cities [Internet]. Routledge; 2006. 192 p. Available from: https://books.google.com/books/ about/Sars.html?hl=\&id=wvqSAgAAQBAJ

26. Huremović D. Preparing for the Outbreak [Internet]. Psychiatry of Pandemics. 2019. p. 65-76. Available from: http://dx.doi. org/10.1007/978-3-030-15346-5_6

27. Wong J, Goh QY, Tan Z, Lie SA, Tay YC, Ng SY, et al. Preparing for a COVID-19 pandemic: a review of operating room outbreak response measures in a large tertiary hospital in Singapore. Can J Anaesth [Internet]. 2020 Jun;67(6):732-45. Available from: http://dx.doi.org/10.1007/s12630-020-01620-9

28. Fuellen G, Liesenfeld O, Kowald A, Barrantes I, Bastian M, Simm A, et al. The preventive strategy for pandemics in the elderly is to collect in advance samples \& data to counteract chronic inflammation (inflammaging). Ageing Res Rev [In- ternet]. 2020 May 23;101091. Available from: http://dx.doi. org/10.1016/j.arr.2020.101091

29. Goh KJ, Wong J, Tien J-CC, Ng SY, Duu Wen S, Phua GC, et al. Preparing your intensive care unit for the COVID-19 pandemic: practical considerations and strategies. Crit Care [Internet]. 2020 May 11;24(1):215. Available from: http://dx.doi. org/10.1186/s13054-020-02916-4

30. Gabriel LEK, Webb SAR. Preparing ICUs for pandemics [Internet]. Vol. 19, Current Opinion in Critical Care. 2013. p. 467-73. Available from: http://dx.doi.org/10.1097/ mcc.0b013e328364d645

31. Tam TWS. Preparing for Influenza Epidemics and Pandemics in the New Millennium [Internet]. Vol. 90, Canadian Journal of Public Health. 1999. p. 293-4. Available from: http://dx.doi. org/10.1007/bf03404511

32. Website [Internet]. [cited 2020 Jun 19]. Available from: Tam TWS. Preparing for Influenza Epidemics and Pandemics in the New Millennium [Internet]. Vol. 90, Canadian Journal of Public Health. 1999. p. 293-4. Available from: http://dx.doi. org/10.1007/bf03404511

33. Hick JL, Biddinger PD. Novel Coronavirus and Old Lessons Preparing the Health System for the Pandemic. N Engl J Med [Internet]. 2020 May 14;382(20):e55. Available from: http:// dx.doi.org/10.1056/NEJMp2005118 